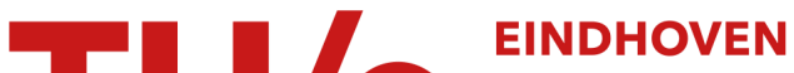 \\ UNIVERSITY OF \\ TECHNOLOGY
}

\section{Supramolecular hydrogels for biomedical applications}

Citation for published version (APA):

Webber, M. J., \& Dankers, P. Y. W. (2019). Supramolecular hydrogels for biomedical applications.

Macromolecular Bioscience, 19(1), [1800452]. https://doi.org/10.1002/mabi.201800452

DOI:

10.1002/mabi.201800452

Document status and date:

Published: 01/01/2019

\section{Document Version:}

Publisher's PDF, also known as Version of Record (includes final page, issue and volume numbers)

\section{Please check the document version of this publication:}

- A submitted manuscript is the version of the article upon submission and before peer-review. There can be important differences between the submitted version and the official published version of record. People interested in the research are advised to contact the author for the final version of the publication, or visit the $\mathrm{DOI}$ to the publisher's website.

- The final author version and the galley proof are versions of the publication after peer review.

- The final published version features the final layout of the paper including the volume, issue and page numbers.

Link to publication

\section{General rights}

Copyright and moral rights for the publications made accessible in the public portal are retained by the authors and/or other copyright owners and it is a condition of accessing publications that users recognise and abide by the legal requirements associated with these rights.

- Users may download and print one copy of any publication from the public portal for the purpose of private study or research.

- You may not further distribute the material or use it for any profit-making activity or commercial gain

- You may freely distribute the URL identifying the publication in the public portal.

If the publication is distributed under the terms of Article $25 \mathrm{fa}$ of the Dutch Copyright Act, indicated by the "Taverne" license above, please follow below link for the End User Agreement:

www.tue.nl/taverne

Take down policy

If you believe that this document breaches copyright please contact us at:

openaccess@tue.nl

providing details and we will investigate your claim. 


\title{
Supramolecular Hydrogels for Biomedical Applications
}

\author{
Matthew J. Webber and Patricia Y. W. Dankers
}

This special issue of Macromolecular Bioscience highlights progress in the emerging class of hydrogel biomaterials constructed from an array of engineered supramolecular interactions. Many different materials, based on an assortment of supramolecular recognition motifs, have been reported and are increasingly being explored for various biomedical applications. Whether these are prepared from non-covalent recognition leading to the formation of physical crosslinks between oligomeric or polymeric building blocks or from physical entanglement of one-dimensional assemblies of small molecule gelators, the resulting hydrogel materials have many properties intimately tied to their supramolecular composition. ${ }^{[1-15]}$ In such hydrogels aimed at biomedical application, relevant properties may include shear-thinning, self-healing transformation in conjunction with extrusion through a syringe as well as relaxation and dissipation of stress through reorganization of crosslinks under a mechanical load. Features of specific interactions, including their affinity and dynamics, also translate across length-scales to alter the bulk properties of these materials; this makes such materials tunable at the level of molecular design. Also, by maintaining the identity of a supramolecular recognition motif, other portions of the molecule or material can be altered without dramatically changing mechanical or geometric features; there are thus opportunities for modular and user-selected "mix-and-match" platforms to augment function in accordance with the demands of a specific application. Finally, the underlying non-covalent interactions may be highly (and reversibly) sensitive to environmental stimuli that include salt, $\mathrm{pH}$, disease analytes, proteins, or enzymes, contrasting with hydrogels prepared from covalent bonds which may be more limited in their response to environmental changes and typically lack reversibility. The applications for such versatile materials are therefore broad, and many new directions are actively being explored.

The pieces enclosed within this special issue include valuable reviews and perspectives alongside original research from some of the world's leaders in the area of supramolecular hydrogels. The types of interactions leveraged in the construction of the materials described are broad, ranging from ordered hydrophobic interactions to host-guest affinity to peptide

Prof. M. J. Webber

University of Notre Dame

Department of Chemical \& Biomolecular Engineering

205 McCourtney Hall, Notre Dame, IN 46556, USA

E-mail: mwebber@nd.edu

Prof. P. Y. W. Dankers

Institute for Complex Molecular Systems

Department of Biomedical Engineering

PO Box 513, Eindhoven, MB 5600, The Netherlands

E-mail: p.y.w.dankers@tue.nl

DOI: 10.1002/mabi.201800452 self-assembly to self-complementary hydrogen bonding motifs. Their uses span application as biomaterials, platforms for tissue engineering, and routes for drug delivery, with cardiovascular, orthopedic, and cancer targets among those described. The breadth encompassed in just these eleven articles is indicative of the many possible routes to the construction of supramolecular hydrogels as well as the myriad number of uses suitable for such materials.

This special issue begins with two excellent reviews highlighting this broad field and the strategies in which materials may be constructed. Varghese and colleagues describe the body of work in the area of stimuli-responsive supramolecular hydrogels for regenerative medicine. ${ }^{[16]}$ This contribution outlines the routes in which such materials are constructed, with a particular focus on the molecular-scale design of these materials and how this approach can result in materials with stimuliresponsive properties. A review from $\mathrm{Ma}$ and colleagues then outlines progress made in the use of supramolecular hydrogels for tissue engineering, ${ }^{[17]}$ with a particular focus on the supramolecular motifs used in the construction of such materials. These two reviews, covering the breadth of this field, offer tremendous design insight at the molecular scale which will serve as tutorials for those interested in pursuing this approach to the design of new hydrogel biomaterials.

The next piece in this issue features original research from Sijbesma and colleagues on the construction of nanocomposite hydrogels from the inclusion of carbon nanotubes within physically crosslinked supramolecular networks. ${ }^{[18]}$ The hydrogels form through hydrophobic association of alkane-rich dimer fatty acid blocks in a PEG-based segmented co-polyester. The addition of carbon nanotubes yields nanocomposite hydrogel materials with increased material toughness and electrical conductivity without sacrificing thixotropic properties or processability. The inclusion of carbon nanotubes furthermore maintains cytocompatibility, with cell viability and proliferation demonstrated.

Research from Appel and colleagues next describes a different approach to the generation of nanocomposite materials through the creation of polymer-nanoparticle hydrogels. ${ }^{[19]}$ Hydrophobic interactions between $\mathrm{C}_{12}$-modified hydroxypropylmethylcellulose and PEG-b-PLA nanoparticles result in threedimensional hydrogel networks amenable to the delivery of a variety of therapeutic payloads. In this work, hydrogels are evaluated for the encapsulation and delivery of several different cell types, with no impact on cell viability or proliferation arising from extrusion of cells within the hydrogels. Furthermore, these hydrogels support three-dimensional cell suspension without settling for long-term culture.

New work from Dankers and colleagues reports on the use of a supramolecular hydrogen bonding motif, ureidopyrimidinone (UPy), to facilitate dynamic pendant presentation of active signals on polymeric assemblies. ${ }^{[20]}$ Endowing a 
presented "guest" signal with a UPy motif facilitates recognition and self-complementary binding to presented UPy on the "host" scaffold. These studies use a combination of microfluidics and fluorescence recovery after photobleaching to quantify signal exchange dynamics in the dilute and hydrogel state, respectively. Understanding the dynamics of signal presentation is an important step in the construction of new modular and bioactive hydrogel biomaterials.

Next, Webber and colleagues review the area of supramolecular hydrogels prepared from macrocyclic host-guest motifs. ${ }^{[21]}$ This contribution reviews the extensive body of work that has used the recognition between synthetic macrocyclic hosts and pendant hydrophobic guests to facilitate physical crosslinking of macromolecules, as well as efforts to induce hydrogelation by threading macrocycles with polymer strands to form poly(pseudo)rotaxanes. The many benefits that arise from the use of recognition of different synthetic motifs are described.

Burdick and colleagues next describe new research using one particularly useful supramolecular motif of a cyclodextrin host and adamantane guest, each attached pendant from a hyaluronic acid (HA) biopolymer backbone. ${ }^{[22]}$ This supramolecular hydrogel is used to encapsulate microgels prepared from norbornene-based photocrosslinking of other modified HA biopolymer. These microgels, prepared through highthroughput microfluidic methods, encapsulate the potent cytokine, Interleukin-10, for its controlled release. When the composite hydrogel system is evaluated in a rat model of myocardial infarction, the combined composite hydrogel releasing IL-10 reduces the number of infiltrating macrophages into the infarct site and improves scar thickness. Interestingly, the composite hydrogel both with and without IL-10 improves cardiac performance, supporting the important role for injectable hydrogels in mediating tissue repair.

Next, von Recum and colleagues describe a hydrogel platform prepared from a covalently crosslinked network of a $\beta$-cyclodextrin pre-polymer for the controlled release of a variety of antibiotic drugs. ${ }^{[23]}$ Through the use of mild synthesis conditions, these hydrogels can be prepared by crosslinking in the presence of a drug guest, a technique known as molecular imprinting. The release rate of encapsulated drug is not dramatically altered for materials where molecular imprinting is employed compared to those where the drug is added after hydrogel formation. However, the amount of drug loaded is significantly higher in cases where the hydrogels were formed in the presence of that specific drug as a template.

A review from Azevedo and colleagues then follows describing the creation of hybrid hydrogels from peptides and polymers. ${ }^{[24]}$ This review covers many different supramolecular interactions between peptides, ranging from coiled-coil motifs to $\beta$-sheet forming segments, and describes how these have been combined with a variety of polymers to achieve hybrid structures through techniques that include pendant attachment of peptides from polymer backbones and electrostatic interactions between self-assembled peptide nanostructures and polymers. This design approach affords opportunities to leverage an assortment of bioactivities from both the peptide and polymer component, as well as modulate mechanical properties of hydrogel networks arising from hybrid materials comprised of both components.
Work from Collier and colleagues next explores the use of supramolecular peptide assemblies in enabling in vitro models of prostate cancer. ${ }^{[25]}$ Specifically, a $\beta$-sheet forming gelator was synthesized that was highly soluble but formed hydrogels under neutral conditions in salt, with the stiffness of these hydrogels tunable by adjusting peptide concentration. Cell viability was maintained over long times in solutions of the soluble peptide prior to hydrogelation, which offers improvement over other peptide gelators where viability is adversely affected by suspending cells in soluble peptides prior to gelation. These peptide-based materials also facilitate spheroid formation from a prostate cancer cell line that are comparable in size to those formed with other self-assembling peptides and matrigel. When evaluated for screening of a prostate cancer drug, the spheroids cultured within the supramolecluar peptide assemblies exhibit concentration-dependent sensitivity. This approach may enable a new 3D cell culture platform to more accurately recreate the tumor microenvironment for applications in in vitro drug screening or therapeutic evaluation.

Finally, Guler and colleagues describe a supramolecular peptide assembly that mimics dentin phosphoprotein, a protein key to the process of mineralization in tooth development. ${ }^{[26]}$ As the native protein function is dictated by the phosphorylation of serine residues, the team developed a peptide wherein serine residues are phosphorylated and can be enzymatically cleaved to control function. Nanofiber assemblies form either through the addition of calcium ions or through enzymatic dephosphorylation. The nanostructural assembles further serve to template hydroxyapatite mineralization and osteogenic differentiation of a cultured cell line.

These eleven exemplary works presented in this special issue serve to illustrate the breadth and possibilities for supramolecular hydrogels in biomedical applications. Design that is strongly rooted to the molecular scale in each of the materials described facilitates a variety of emergent properties that contribute utility in their application. The interdisciplinary flavors of this field are also clearly evident, with elegant chemical design meeting robust material characterization to enable biological applications. Ultimately, some of the materials discussed will then traverse the pathway to clinical translation to impact the lives of patients. These features will surely serve to excite the field and draw in a variety of new perspectives as momentum builds in developing and assessing these different technologies.

[1] M. J. Webber, E. A. Appel, E. W. Meijer, R. Langer, Nat. Mater. 2016, $15,13$.

[2] J. K. Sahoo, M. A. VandenBerg, M. J. Webber, Adv. Drug Delivery Rev. 2018, 127, 185.

[3] D. J. Wu, C. V. C. Bouten, P. Y. W. Dankers, Curr. Opin. Biomed. Eng. 2017, 2, 43.

[4] P. Y. W. Dankers, E. W. Meijer, Bull. Chem. Soc. Jpn. 2007, 80, 2047.

[5] H. Cui, M. J. Webber, S. I. Stupp, Biopolymers 2010, 94, 1.

[6] J. B. Matson, R. H. Zha, S. I. Stupp, Curr. Opin. Solid State Mater. Sci. 2011, 15, 225.

[7] X. Du, J. Zhou, J. Shi, B. Xu, Chem. Rev. 2015, 115, 13165.

[8] R. Freeman, J. Boekhoven, M. B. Dickerson, R. R. Naik, S. I. Stupp, MRS Bull. 2015, 40, 1089.

[9] S. I. Stupp, MRS Bull. 2005, 30, 546. 
[10] R. J. Mart, R. D. Osborne, M. M. Stevens, R. V. Ulijn, Soft Matter 2006, 2, 822

[11] T. Aida, E. W. Meijer, S. I. Stupp, Science 2012, 335, 813

[12] R. V. Ulijn, N. Bibi, V. Jayawarna, P. D. Thornton, S. J. Todd, R. J. Mart, A. M. Smith, J. E. Gough, Mater. Today 2007, 10, 40.

[13] E. A. Appel, J. del Barrio, X. J. Loh, O. A. Scherman, Chem. Soc. Rev. 2012, 41, 6195.

[14] M. J. Webber, R. Langer, Chem. Soc. Rev. 2017, 46, 6600.

[15] M. J. Webber, Bioeng. Transl. Med. 2016, 1, 252.

[16] J. Hoque, N. Sangaj, S. Varghese, Macromol. Biosci. 2019, 1, 1800259.

[17] L. Saunders, P. X. Ma, Macromol. Biosci. 2019, 1, 1800313.

[18] M. Mihajlovic, M. Mihajlovic, P. Y. W. Dankers, R. Masereeuw, R. P. Sijbesma, Macromol. Biosci. 2019, 1, 1800173.

[19] H. Lopez Hernandez, A. K. Grosskopf, L. M. Stapleton, G. Agmon, E. A. Appel, Macromol. Biosci. 2019, 1, 1800275.
[20] M. M. C. Bastings, T. M. Hermans, A. J. H. Spiering, E. W. L. Kemps L. Albertazzi, E. E. Kurisinkal, P. Y. W. Dankers, Macromol. Biosci. 2019, 1, 1800296.

[21] S. M. Mantooth, B. G. Munoz-Robles, M. J. Webber, Macromol. Biosci. 2019, 1, 1800281.

[22] M. H. Chen, J. J. Chung, J. E. Mealy, S. Zaman, E. C. Li, M. F. Arisi, P. Atluri, J. A. Burdick, Macromol. Biosci. 2019, 1, 1800248.

[23] D. Juric, N. A. Rohner, H. A. von Recum, Macromol. Biosci. 2019, 1, 1800246.

[24] E. Radvar, H. S. Azevedo, Macromol. Biosci. 2019, 1, 1800221.

[25] K. M. Hainline, F. Gu, J. F. Handley, Y. F. Tian, Y. Wu, L. de Wet, D. J. Vander Griend, J. H. Collier, Macromol. Biosci. 2019, 1, 1800249.

[26] G. Gulseren, G. Tansik, R. Garifullin, A. B. Tekinay, M. O. Guler, Macromol. Biosci. 2019, 1, 1800080. 